\title{
PENGARUH MODEL COOPERATIF SCRIPT BERBASIS TRI HITA KARANA TERHADAP KOMPETENSI PENGETAHUAN IPS SISWA KELAS IV
}

\author{
${ }^{1}$ I Kadek Wibisana, ${ }^{2}$ Ni Nyoman Kusmariatni, ${ }^{3}$ Kadek Yudiana \\ 1,2,3 Jurusan Pendidikan Dasar Universitas Pendidikan Ganesha \\ e-mail: wibisana54@gmail.com, nyoman.kusmariyatni@undiksha.ac.id, \\ kadek.yudiana@undiksha.ac.id
}

\begin{abstract}
ABSTRAK
Penelitian ini bertujuan untuk mengetahui perbedaan yang signifikan kompetensi pengetahuan IPS antara siswa yang dibelajarkan menggunakan model Pembelajaraan Cooperatif Script Berbasis Tri Hita Karana pada siswa kelas IV di Gugus IV Kecamatan Tampaksiring Tahun Pelajaran 2018/2019. Jenis penelitian ini adalah penelitian eksperimen semu dengan rancangan penelinitian Non Equivalent Post-test Only Control Group Design, populasi penelitian siswa kelas IV SD Gugus IV Kecamatan Tampaksiring Tahun Pelajaran 2018/2019 yang berjumlah 110 siswa. Hasil uji kesetaraan bahwa populasi penelitian menunjukkan hasil yang setara. Dengan demikian sampel penelitian dapat ditentukan dengan teknik random sampling. Sampel penelitian ini yaitu kelas IV SD Negeri 2 Pejeng Kangin dan 3 Pejeng Kangin yang berjumlah 48 siswa. Data hasil belajar dikumpulkan dengan menggunakan tes yaitu dengan tes obyektif. Data yang diperoleh dianalisis menggunakan analisis statistik deskriptif, t-test, diperoleh $t_{\text {hitung }}$ sebesar 3,062. Sedangkan $t_{\text {tabel }}$ dengan $\mathrm{db}=46$ dan taraf signifikansi $5 \%$ adalah 2,000. Hal ini berarti $t_{\text {hitung }}$ lebih besar dari $t_{\text {tabel }}$ ( $t_{\text {hitung }}>t_{\text {tabel }}$ ) sehingga $\mathrm{H}_{0}$ ditolak atau $\mathrm{H}_{1}$ diterima. Dengan demikian, dapat diinterpretasikan bahwa terdapat Pengaruh Model Pembelajaran Cooperatif Script Berbasis Tri Hita Karana Terhadap kompetensi Pengetahuan IPS Pada Siswa SD Kelas IV di Gugus IV Kecamatan Tampaksiring.
\end{abstract}

Kata kunci: , Cooperatif Script, IPS, Tri Hita Karana.

\begin{abstract}
This study aims to find out there is a significant difference between students' competence IPS knowledge that learned using the model of learning cooperatif Tri Hita Karana Script Based on the fourth grade students in Cluster IV District Tampaksiring in academic year 2018/2019. The research is a quasi-experimental research design with penelinitian Non Equivalent Post-test Only Control Group Design, the study population cluster fourth grade students Tampaksiring District IV Academic Year 2018/2019, amounting to 110 students. The test results of equality that the study population showed similar results. Thus the sample can be determined by random sampling technique. Samples of this study is the fourth grade of SD Negeri 2 and 3 Pejeng Pejeng Kangin Kangin of 48 students. Learning outcomes data was collected using a test that is the objective test. Data were analyzed using descriptive statistical analysis, t-test, obtained t of 3.062. While ttabel with $\mathrm{db}=46$ and $5 \%$ significance level is 2.000. This means that $t$ is greater than $t$ table ( $t>t$ table) so $\mathrm{H} 0 \mathrm{H} 1$ rejected or accepted. Thus, it can be interpreted that there Effect of Script-Based Learning Model cooperatif Tri Hita Karana Against competence IPS Knowledge Elementary Students of Class IV in Cluster IV District Tampaksiring.
\end{abstract}

Key words: Cooperatif Script, IPS, Tri Hita Karana. 
I Kadek Wibisana, Ni Nyoman Kusmariatni, Kadek Yudiana. (2019). Jurnal Pendidikan Multikultural Indonesia. Vol. 2 (2) pp. 66-75.

\section{PENDAHULUAN}

Pendidikan sudah menjadi suatu hal yang sangat dibutuhkan dan harus dikembangkan dalam kehidupan manusia pada saat ini. Pendidikan adalah proses terkait dengan potensi (kemampuan, kapasitas) manusia yang mudah dipengaruhi oleh kebiasaan, supaya disempurnakan dengan kebiasaan baik, melalui media yang disusun dan dikelola sedemikian rupa oleh manusia untuk menolong orang lain atau dirinya sendiri dalam mencapai tujuan yang ditetapkan (Purwanto, 2014:22). Pendidikan tidak hanya berasal dari apa yang telah ada dalam dunia ini tapi juga berasal dari intraksi yang diciptakan oleh manusia itu sendiri. Interaksi yang tercipta dari kehidupan sosial masyarakat merupakan ilmu yang penting untuk diahami oleh siswa sejak dini. Pendidikan didapat manusia tidak hanya dari sekolah melainkan juga dari lingkungan keluarga dan masyarakat. Sekolah Dasar menjadi titik awal seorang manusia memulai pembelajaran yang menjadi pondasi untuk dirinya di kemudian hari dalam menerima pembelajaran selanjutnya. Pendidikan di sekolah dasar bertujuan untuk memberi peserta didik kemampuan dasar yang berupa pengetahuan, keterampilan, dan sikap yang akan berguna bagi dirinya sesuai dengan tingkat perkembangannya. Berbagai mata pelajaran diajarkan di tingkat sekolah dasar salah satunya Ilmu Pengetahuan Sosial (IPS).

IImu Pengetahuan Sosial (IPS) merupakan pengetahuan terpadu yang dilakukan disekolah-sekolah antara lain untuk menyumbangkan kepekaan anak didik terhadap kehidupan sosial sekitarnya agar kelak mereka menjadi warga Negara yang baik (Tjandra,dkk, 2005:2). Dalam pembelajaran IImu Pengetahuan Sosial (IPS) banyak unsurunsur yang terkandung didalamnya seperti unsur geografi, sejarah, ekonomi, hukum dan politik, kewarganegaraan, sosiologi, dan juga bidang humaniora, pendidikan dan agama (Trianto, 2012:177). Unsur pembentuk inilah yang menjadikan pembelajaran IPS itu sangat penting diajarkan untuk anak-anak dari jenjang SD sampai Perguruan Tinggi. Apa sebab kita harus mempelajari pembelajaran IPS ini karena dalam pembelajaran ini siswa akan diajarkan banyak hal seperti: a). Pembelajaran hubungan manusia dengan manusia/humaniora, b). Pembelajaran hubungan antara manusia dengan lingkungan/geografi, c). Pembelajaran hubungan antara manusia dengan tuhan/agama. Ketiga hubungan yang disebutkan itu sama dengan ajaran yang di ajarkan dalam ajaran agama hindu yaitu ajaran falsafah Tri Hitha Karana yang didalamnya ada Parahyangan, Pawongan, dan Palemahan. Parahyangan, hubungan antara manusia dengan Tuhan, Pawongan hubungan antara manusia dengan manusia, Palemahan hubungan antara manusia dengan lingkungannya. Dari pernyataan yang sudah dipaparkan diatas diharapkan pembelajaran IImu Pengetahuan Sosial mampu membentuk siswa menjadi manusia yang bisa menjalin hubungan yang baik antara manusia dengan manusia, manusia dengan lingkungan dan manusia dengan tuhan.

Pelaksanaan proses pembelajaran di dalam kelas perlu didesain dengan kreatif dan inovatif. Pembelajaran yang belum menggunakan model pembelajaran yang bervariasi cenderung menyebabkan siswa menjadi kurang aktif dalam kegiatan pembelajaran di dalam kelas. Keadaan ini menyebabkan siswa yang memiliki kemampuan di atas rata-rata yang akan aktif sedangkan siswa yang lainnya hanya akan mendengarkan dan menunggu perintah dari gurunya. Hal tersebut terlihat dari hasil observasi yang telah dilaksanakan pada tanggal 18 Januari 2019 dengan guru kelas IV di Sekolah Dasar Gugus IV Kecamatan Tampaksiring diperoleh hasil berupa, sebagian besar guru kelas masih kurang dalam menerapkan model pembelajaran yang kreatif dan inovatif dalam proses pembelajaran khususnya IImu Pengetahuan Sosial. Hal ini diperkuat dengan nilai kompetensi siswa pada mata pelajaran IImu Pengatahuan Sosial yang masih rendah. Rata-rata nilai kompetensi IImu Pengetahuan Sosial di kelas IV Sekolah Dasar Gugus IV Kecamatan Tampaksiring dapat dilihat pada tabel 1 . 
I Kadek Wibisana, Ni Nyoman Kusmariatni, Kadek Yudiana. (2019). Jurnal Pendidikan Multikultural Indonesia. Vol. 2 (2) pp. 66-75.

Tabel 1. Rata-rata Nilai UAS IImu Pengetahuan Sosial di Kelas IV pada Semester 1

\begin{tabular}{|c|c|c|c|c|c|c|}
\hline \multirow[t]{2}{*}{ No } & \multirow[t]{2}{*}{ Nama Sekolah } & \multirow{2}{*}{$\begin{array}{c}\text { Jumlah } \\
\text { Siswa }\end{array}$} & \multirow{2}{*}{$\begin{array}{l}\text { Rata-rata } \\
\text { Nilai UAS }\end{array}$} & \multirow[t]{2}{*}{ KKM } & \multicolumn{2}{|c|}{ Nilai Siswa } \\
\hline & & & & & $\begin{array}{c}\text { Dibawah } \\
\text { KKM }\end{array}$ & $\begin{array}{c}\text { Diatas } \\
\text { KKM }\end{array}$ \\
\hline 1 & SDN 1 Pejeng Kangin & 35 & 68,03 & 70 & 19 & 16 \\
\hline 2 & SDN 2 Pejeng Kangin & 27 & 67,56 & 70 & 16 & 11 \\
\hline 3 & SDN 3 Pejeng Kangin & 21 & 66,14 & 70 & 12 & 9 \\
\hline 4 & SDN 1 Pejeng Kelod & 13 & 69,15 & 70 & 8 & 5 \\
\hline 5 & SDN 2 Pejeng Kelod & 14 & 69,43 & 70 & 8 & 6 \\
\hline
\end{tabular}

Berdasarkan data tabel tersebut telah terjadi kesenjangan antara harapan dan kenyataan dalam mata pelajaran IImu Pengetahuan Sosial, dimana masih ada sebagian yang masih berada dibawah KKM. Untuk mengatasi permasalahan tersebut guru perlu membuat inovasi baru dalam pembelajaran IImu Pengetahuan Sosial di dalam kelas. Banyak cara yang dapat meningkatkan keaktifan siswa dalam belajar IPS seperti penggunaan media gambar, audio visual, pengamatan langsung, permainan dan dengan penggunaan model pembelajaran yang inovatif seperti model pembelajaran Cooperative Script. Cooperative Scripts merupakan model pembelajaran dimana dalam proses pembelajaran siswa bekerja dalam berpasangan dan secara bergantian menyampaikan bagian materi kemudian saling bergantian juga menambahkan saat menjadi penyimak jika ada dirasa kurang dari yang disampaikan oleh lawan bicara (Huda:2013). Hal yang sama juga disampaikan oleh Kurniasih dan Sani (2016:120) "Model pembelajaran Cooperative Script merupakan metode pembelajaran berpasang-pasangan dan masing-masing individu dalam pasangan yang ada mengiktisarkan materi-materi yang telah dipelajari". Dari pengertian yang diungkapkan keduanya memiliki maksud yang sama yaitu proses pembelajaran dengan cara berpasangan dan menyampaikan rangkuman materi yang bertujuan untuk memecahkan masalah dengan cepat dan efesien.

Model pembelajaran Cooperative Scripts ini membuat siswa menjadi lebih aktif dalam pembelajaran. Adapun kelebihan dari model pembelajaran Cooperative Script menurut Kurniasih dan Sani (2016:120) adalah, Dengan model pembelajaran ini, dengan sendirinya siswa dilatih untuk lebih teliti, tekun dan rajin, karena mereka sendirilah yang akan menyimpulkan materi yang diberikan, setiap siswa mendapat bagian dalam pembelajaran, melatih mengungkapkan kesalahan orang lain dengan lisan.

Melihat kelebihan-kelebihan model pembelajaran Cooperative Scripts yang ada diatas maka pembelajaran yang dilakuan sebelumnya dikatakan kurang aktif menjadi lebih aktif karena siswa dilatih untuk mengungkapkan dan menyampaikan secara langsung pendapat mereka tentang materi yang disampaikan. Pembelajaran menjadi lebih menarik apabila model Cooperative Scripts berbasis Tri Hita Karana. Perlu diketahui bahwa dengan berbantuan Tri Hita Karana lebih menumbuhkan rasa peka siswa terhadap lingkungan yang ada di sekitarnya. Geriya (dalam Laksmi, 2013) menyatakan kearifan local Tri Hita Karana merupakan suatu ajaran agama yang dapat diintegrasikan dalam pembelajaran dan memiliki tiga unsur yang menyebabkan hubungan harmonis, bersumber dari menjaga keharmonisan hubungan antara manusia dengan Tuhan (parhayangan), manusia dengan manusia (pawongan), dan manusia dengan alam lingkungannya (palemahan). Dalam kontek Tri Hita Karana (THK), manusia baru memiliki makna dalam hubungannya dengan manusia lainnya, Sang Pencipta, dan alam (Suja, 2010:33).

Penelitian dengan menggunakan model Cooperative Script pernah dilakukan oleh Yulianto pada tahun 2014 dengan hasil penelitian yang diperoleh dalam penelitian yang berjudul Penggunaan Model Kooperatif Tipe Cooperative Script dalam Peningkatan Pembelajaran IPS pada Siswa Kelas V SD Negeri Widarapayung Wetan 02 Tahun Ajaran

Pengaruh Model Cooperatif Script Berbasis Tri Hita Karana Terhadap Kompetensi Pengetahuan Ips 
2013/2014, menunjukkan bahwa penggunaan model kooperatif tipe cooperative script dapat meningkatkan pembelajaran IPS pada siswa kelas V SD Negeri Widarapayung Wetan 02 Tahun 2014. Penelitian menggunakan model Cooperative Script berbasis tri hita karana tepat digunakan untuk mengatasi permasalahan yang ada di kelas IV Sekolah Dasar Gugus IV Kecamatan Tampaksiring dibandingkan dengan model konvensional yang diterapkan sebelumnya pada kelas IV Sekolah Dasar Gugus IV Kecamatan Tampaksiring. Pembaruan yang dilaksanakan pada penelitian ini bertujuan agar Tri Hita Karana yang merupakan pedoman hidup bagi umat hindu dapat ditanamkan sejak dini yaitu sejak duduk di sekolah dasar. Adapun penelitian ini bertujuan untuk mengetahui perbedaan yang signifikan kompetensi pengetahuan IPS antara siswa yang dibelajarkan menggunakan model Pembelajaraan Cooperatif Script Berbasis Tri Hita Karana dengan siswa yang dibelajarkan menggunakan model konvesional.

\section{METODE}

Penelitian ini menggunakan rancangan non equivalent post-test only control group design. Dalam penelitian ini dibandingkan kompetensi pengetahuan menggunakan model pembelajaran Cooperatif Script dengan tidak menggunakan model pembelajaran Cooperatif Script terhadap kompetensi pengetahuan siswa dalam mata pelajaran IImu Pengetahuan Sosial. Prosedur yang ditempuh dalam penelitian ini terdiri dari tiga tahapan yaitu tahap persiapan, tahap pelaksanaan, dan tahap akhir eksperimen. Populasi dalam penelitian ini adalah seluruh kelas IV SD di Gugus IV Kecamatan Tampaksiring. Pada gugus ini terdapat 5 sekolah yaitu SD Negeri 1 Pejeng Kangin, SD Negeri 2 Pejeng Kangin, SD Negeri 3 Pejeng Kangin, SD Negeri 1 Pejeng Kelod, dan SD Negeri 2 Pejeng Kelod dengan seluruh jumlah populasi adalah 110 siswa. Berdasarkan Ramdom Sampling, sampel dalam penelitian ini yaitu kelompok siswa kelas IV di SD N 2 Pejeng Kangin yang berjumlah 27 orang sebagai kelompok eksperimen dan kelompok siswa kelas IV di SD N 3 Pejeng Kangin yang berjumlah 21 orang sebagai kelompok control.

Dalam penelitian ini metode yang digunakan dalam pengumpulan data adalah metode tes dengan menggunakan tes objektif. Tes objektif digunakan dalam akhir pembelajaran. Metode dan teknik analisis data yang digunakan dalam penelitian ini adalah metode kuantitatif deskriptif. Metode kuantitatif deskriptif menunjukkan perbedaan antara kompetensi pengetahuan siswa yang diajarkan dengan model Cooperative Script dengan yang menggunakan model konvensional

\section{HASIL DAN PEMBAHASAN}

Data yang diperoleh dari hasil Post-test siswa kelompok eksperimen digunakan untuk mencari skor kompetensi pengetahuan IPS dari kelas eksperimen dengan tujuan untuk mengetahui kemampuan siswa setelah diberikan perlakuan. Data skor Post-Test kompetensi pengetahuan IPS kelompok eksperimen menunjukkan bahwa skor tertinggi adalah 26 dan skor terendah 15 dengan rentangan skor $0-11$. Rentangan data hasil post test $(\mathrm{R})$ sebesar 12 , banyaknya kelas interval post test $(\mathrm{K})$ sebesar 6 , panjang kelas interval post test $(\mathrm{P})$ sebesar 2 . Berdasarkan rentangan data $(\mathrm{R})$, banyaknya kelas interval $(\mathrm{K})$, dan panjang kelas interval (P) maka deskripsi frekuensi skor post-test kelompok eksperimen dapat dilihat pada $\quad$ Tabel

Tabel 2. Deskripsi Frekuensi Skor Post-test Kelompok Eksperimen

\begin{tabular}{lllll}
\hline No & Interval & $\begin{array}{l}\text { Titik Tengah } \\
(\mathrm{X})\end{array}$ & Frekuensi Absolut $(\mathrm{f})$ & $\begin{array}{l}\text { Frekuensi } \\
\text { Komulatif }(\mathrm{F})\end{array}$ \\
\hline 1 & $15-16$ & 15,5 & 3 & 3 \\
2 & $17-18$ & 17,5 & 4 & 7 \\
3 & $19-20$ & 19,5 & 5 & 12 \\
\hline
\end{tabular}

Pengaruh Model Cooperatif Script Berbasis Tri Hita Karana Terhadap Kompetensi Pengetahuan Ips 
I Kadek Wibisana, Ni Nyoman Kusmariatni, Kadek Yudiana. (2019). Jurnal Pendidikan Multikultural Indonesia. Vol. 2 (2) pp. 66-75.

\begin{tabular}{lllll}
\hline 4 & $21-22$ & 21,5 & 5 & 17 \\
5 & $23-24$ & 23,5 & 7 & 24 \\
6 & $25-26$ & 25,5 & 3 & 27 \\
\multicolumn{2}{l}{\begin{tabular}{l} 
Jumlah \\
\hline
\end{tabular}} & & 27 & \\
\hline
\end{tabular}

Berdasarkan tabel 2, selanjutnya dilakukan menyusun tabel konversi untuk menentukan kategori skor kompetensi pengetahuan IPS terlebih dahulu dihitung dengan mean ideal (Mi) dan standar deviasi ideal (SDi), yang mana hasilnya adalah sebesar 5.

Berdasarkan kategori rentangan interval rata-rata skor pemahaman konsep dengan menggunakan model Pembelajaraan Cooperatif Script Berbasis Tri Hita Karana adalah 20,78 Berada pada interval $17,5 \leq \bar{X} \leq 22,5$. Berdasarkan kategori rentangan interval dapat disimpulkan bahwa data kompetensi pengetahuan IPS siswa yang menggunakan model Pembelajaraan Cooperatif Script Berbasis Tri Hita Karana termasuk pada kategori "Tinggi". Secara visualisasi kompetensi pengetahuan IPS yang menggunakan model Pembelajaraan Cooperatif Script Berbasis Tri Hita Karana dapat disajikan ke dalam grafik poligon pada Gambar 1.

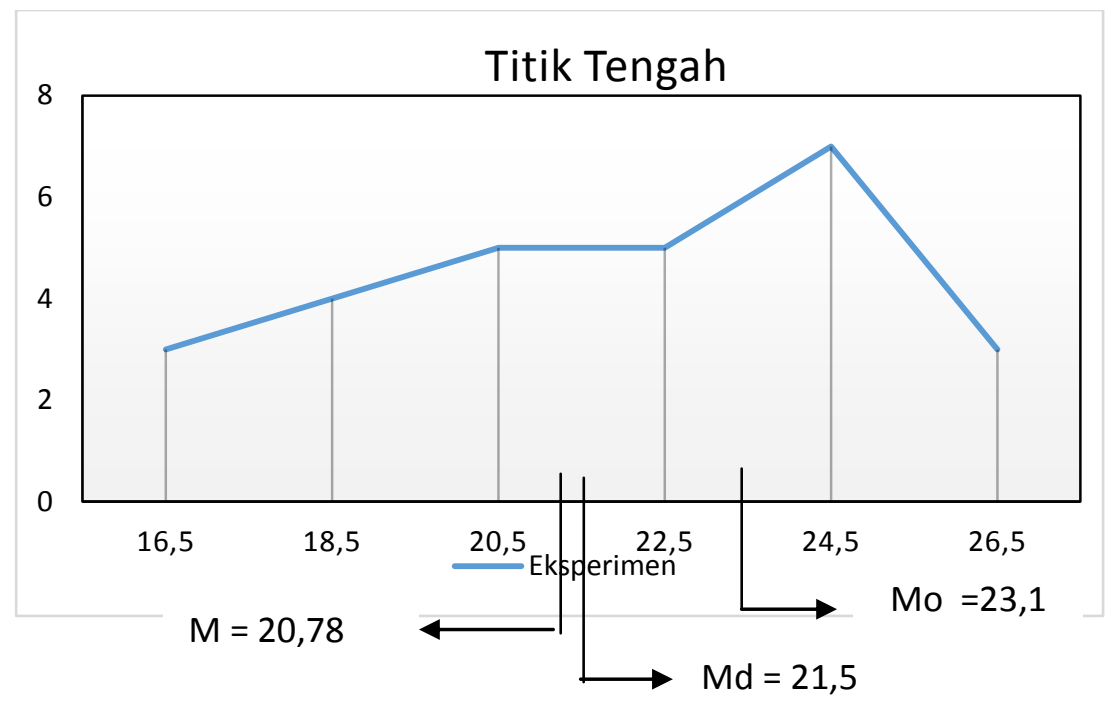

Gambar 1. Histogram skor kompetensi pengetahuan IPS siswa kelas eksperimen.

Data hasil Post-test siswa kelompok kontrol digunakan untuk mencari skor kompetensi pengetahuan IPS dari kelas kontrol dengan tujuan untuk mengetahui kemampuan siswa setelah diberikan perlakuan. Data skor Post-Test kompetensi pengetahuan IPS kelompok kontrol menunjukkan bahwa skor tertinggi adalah 22 dan skor terendah 13 dengan rentangan skor 0-9. Rentangan data hasil post test $(R)$ sebesar 10 , banyaknya kelas interval post test $(\mathrm{K})$ sebesar 5 , panjang kelas interval post test $(\mathrm{P})$ sebesar 2. Berdasarkan rentangan data $(R)$, banyaknya kelas interval $(K)$, dan panjang kelas interval (P) maka deskripsi frekuensi skor post-test kelompok kontrol dapat dilihat pada Tabel 3.

Tabel 3. Deskripsi Frekuensi Skor Post-test Kelompok Kontrol

\begin{tabular}{ccccc}
\hline No & Interval & $\begin{array}{c}\text { Titik Tengah } \\
(\mathrm{X})\end{array}$ & Frekuensi Absolut (f) & $\begin{array}{c}\text { Frekuensi Komulatif } \\
(\mathrm{F})\end{array}$ \\
\hline 1 & $13-14$ & 13,5 & 4 & 4 \\
2 & $15-16$ & 15,5 & 6 & 10 \\
3 & $17-18$ & 17,5 & 5 & 15 \\
4 & $19-20$ & 19,5 & 3 & 18 \\
5 & $21-22$ & 21,5 & 3 & 21
\end{tabular}

Pengaruh Model Cooperatif Script Berbasis Tri Hita Karana Terhadap Kompetensi Pengetahuan Ips 
Berdasarkan tabel 3, selanjutnya dilakukan menyusun tabel konversi untuk menentukan kategori skor kompetensi pengetahuan IPS terlebih dahulu dihitung dengan mean ideal (Mi) dan standar deviasi ideal (SDi), yang mana hasilnya adalah sebesar 5 .

Berdasarkan kategori rentangan interval rata-rata skor pemahaman konsep dengan menggunakan model konvensional rata-rata skor kompetensi pengetahuan IPS siswa yang bukan menggunakan model pembelajaran konvensional adalah 16,86. Berada pada interval $12,5 \leq \bar{X}<17,45$. Berdasarkan tabel di atas, dapat disimpulkan bahwa data kompetensi pengetahuan IPS siswa yang menggunakan model pembelajaran konvensional pada kategori "Sedang". Secara visualisasi kompetensi pengetahuan IPS yang menggunakan model konvensional dapat disajikan ke dalam grafik poligon pada gambar 2 .

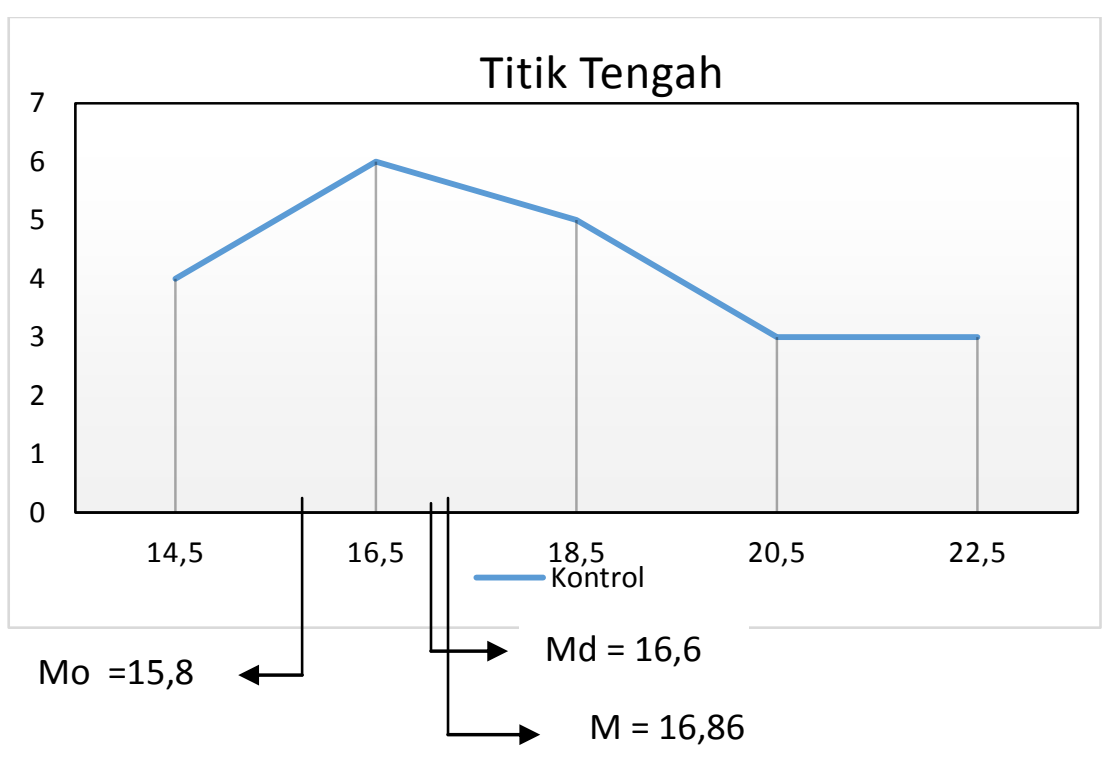

Gambar 2. Histogram skor kompetensi pengetahuan IPS siswa kelas eksperimen.

Pada penelitian ini uji normalitas data dilakukan dengan analisis Chi-Kuadrat dengan kriteria pengujian data berdistribusi normal jika $\chi^{2}$ hit $<\chi^{2}$ tabel, dengan taraf signifikansi $5 \%$ dan derajat kebebasan $\mathrm{dk}=(\mathrm{k}$ - parameter-1). Berdasarkan hasil perhitungan uji normalitas post-test kelompok eksperimen, diperoleh $\chi_{\text {hit }}^{2}=5,461$ dan $\chi_{\text {tabel }}^{2}=7,815$ pada taraf signifikansi $5 \%$ dan $\mathrm{db}=6-2-1=3$. Ini berarti bahwa $\chi^{2}{ }_{\text {hit }}<\chi^{2}$ tabel, maka data hasil post-test kelompok eksperimen berdistribusi normal. Sedangkan hasil perhitungan uji normalitas posttest kelompok kontrol, diperoleh $\chi^{2}{ }_{\text {hit }}=1,435$ dan $\chi^{2}{ }_{\text {tabel }}=5,591$ pada taraf signifikansi $5 \%$ dan $\mathrm{db}=5-2-1=2$. Ini berarti bahwa $\chi^{2}$ hit $<\chi^{2}$ tabel, maka data hasil post-test kelompok kontrol berdistribusi normal.

Uji homogenitas dilakukan terhadap varians pasangan antar kelompok eksperimen dan kontrol. Uji yang digunakan adalah uji-F dengan kriteria data homogen jika $F_{\text {hitung }}<F_{\text {tabel. }}$. Ringkasan hasil uji homogenitas varians antar kelompok eksperimen dan kontrol disajikan pada Tabel 3.

Tabel 3. Ringkasan Hasil Uji Homogenitas Kelompok Eksperimen dan Kelompok Kontrol.

\begin{tabular}{cccc}
\hline Kelompok Data Hasil Belajar & $\mathrm{F}_{\text {hitung }}$ & $\mathrm{F}_{\text {tabel }}$ & Status \\
\hline Eksperimen & 1,36 & 2,12 & Homogen
\end{tabular}

Pengaruh Model Cooperatif Script Berbasis Tri Hita Karana Terhadap Kompetensi Pengetahuan Ips 
Kontrol

Berdasarkan tabel di atas, diketahui $F_{\text {hitung }}$ kompetensi pengetahuan IPS siswa kelompok eksperimen dan kontrol adalah 1,36. Sedangkan $F_{\text {tabel }}$ dengan $\mathrm{db}_{\text {pembilang }}=24$, $\mathrm{db}_{\text {penyebut }}=21$, dan taraf signifikansi $5 \%$ adalah 2,12. Hal ini berarti $F_{\text {hitung }}<F_{\text {tabel }}$ sehingga varians data kompetensi pengetahuan IPS siswa kelompok eksperimen dan kontrol adalah homogen.

\section{Uji Hipotesis Penelitian}

Pengujian hipotesis dilakukan dengan menggunakan uji-t sampel independent (tidak berkorelasi) dengan rumus polled varians dengan kriteria $\mathrm{H}_{0}$ tolak jika $t_{\text {hitung }}>t_{\text {tabel }}$ dan $\mathrm{H}_{0}$ terima jika $t_{\text {hitung }}<t_{\text {tabel. }}$. Ringkasan uji hipotesis disajikan pada Tabel 4.

Tabel 4. Ringkasan Hasil Uji Hipotesis.

\begin{tabular}{lcccccc}
\hline \multicolumn{1}{c}{ Hasil Belajar } & $\begin{array}{c}\text { Standar } \\
\text { Deviasi }\end{array}$ & $\mathrm{N}$ & $\mathrm{Db}$ & $\mathrm{t}_{\text {hitung }}$ & $\mathrm{t}_{\text {tabel }}$ & Kesimpulan \\
\hline Kelompok & 20,78 & 27 & 46 & 3,062 & 2,000 & $\mathrm{H}_{0}$ ditolak \\
$\begin{array}{l}\text { Eksperimen } \\
\text { Kelompok Kontrol }\end{array}$ & 16,86 & 21 & & & & \\
\hline
\end{tabular}

Berdasarkan hasil perhitungan uji-t, diperoleh $t_{\text {hitung }}$ sebesar 3,062 . Sedangkan $t_{\text {tabel }}$ dengan $\mathrm{db}=46$ dan taraf signifikansi $5 \%$ adalah 2,000. Hal ini berarti $t_{\text {hitung }}$ lebih besar dari $t_{\text {tabel }}$ ( $t_{\text {hitung }}>t_{\text {tabel }}$ ) sehingga $H_{0}$ ditolak atau $H_{1}$ diterima. Dengan demikian, dapat diinterpretasikan bahwa terdapat Perbedaan Model Pembelajaran Cooperatif Script Berbasis Tri Hita Karana Terhadap kompetensi Pengetahuan IPS Pada Siswa SD Kelas IV di Gugus IV Kecamatan Tampaksiring Tahun Pelajaran 2018/2019

\section{PEMBAHASAN}

Berdasarkan rata-rata skor hasil belajar siswa yang menggunakan model pembelajaran Kooperatif Script Berbasis Tri Hita Karana adalah 20,78 dan rata-rata skor siswa yang menggunakan model konvensional adalah 16,86. Hal ini menunjukkan bahwa kompetensi belajar siswa yang dibelajarkan dengan model pembelajaran Kooperatif Script Berbasis Tri Hita Karana lebih tinggi dibandingkan dengan kelompok siswa yang menggunakan model konvensional.

Berdasarkan analisis data menunjukkan terdapat perbedaan kompetensi pengetahuan ilmu pengetahuan sosial antara siswa yang dibelajarkan dengan model pembelajaran Kooperatif Script Berbasis Tri Hita Karana dengan siswa yang dibelajarkan model konvensional. Tinjauan ini didasarkan pada hasil perhitungan uji-t dan rata-rata skor hasil belajar siswa. Analisis data mengunakan uji-t, diketahui $f_{\text {hit }}=3,062$ dan $f_{\text {tab }}$ pada taraf signifikansi $5 \%=2,000$. Hasil perhitungan tersebut menunjukkan bahwa $F_{\text {hit }}>F_{\text {tab }}$, sehingga hasil penelitian adalah signifikan. Hal ini berarti terdapat perbedaan kompetensi pengetahuan ilmu pengetahuan sosial antara siswa yang dibelajarkan dengan model pembelajaran Kooperatif Scripts Berbasis Tri Hita Karana dengan siswa yang dibelajarkan model konvensional Pada Siswa SD Kelas IV di Gugus IV Kecamatan Tampaksiring Tahun Pelajaran 2018/2019.

Pembelajaran Kooperatif tipe Script adalah salah satu bentuk atau model pembelajaran kooperatif. Menurut Slavin (dalam Shoimin, 2014:49) "model Kooperatif Script merupakan model pembelajaran yang dapat meningkatkan daya ingat siswa". Hal tersebut sangat membantu siswa dalam mengembangkan serta mengaitkan fakta-fakta dan konsepkonsep yang pernah didapatkan dalam pemecahan masalah. Hal senada juga disampaikan oleh Kurniasih dan Sani (2016:120) model pembelajaran Cooperatif Script merupakan Pengaruh Model Cooperatif Script Berbasis Tri Hita Karana Terhadap Kompetensi Pengetahuan Ips 
"metode pembelajaran berpasang-pasangan dan masing-masing individu dalam pasangan yang mengikhtisarkan materi-materi yang telah dipelajari. Dari beberapa pendapat yang telah disampaikan dapat disimpulkan bahwa model pembelajaran cooperatif script adalah model pembelajaran secara berpasangan dan masing-masing individu secara bergantian mengikhtisarkan bagian-bagian dan materi yang telah dipelajari sehingga dapat meningkatkan daya ingat siswa.

Model pembelajaran cooperatif script memiliki kelebihan yaitu: 1). Dengan model pembelajaran Cooperatif Script siswa dilatih untuk lebih teliti, tekun dan rajin dalam memahami pembelajaran kompetensi ilmu pengetahuan sosial yang didapatkan karena setelah pembelajaran siswa sendiri yang akan menyimpulkan materi yang diberikan. 2). Setiap siswa akan mendapat bagian dalam proses pembelajaran yang sedang berlangsung. 3). Melatih meningkatkan daya pikir siswa dan mengungkapkan kesalahan orang lain.

Model Cooperatif Script yang diterapkan dalam penelitian ini diharapkan siswa akan mendapatkan pemahaman yang lebih baik mengenai materi pembelajaran kompetensi pengetahuan ilmu pengetahuan sosial dan akan lebih tertarik terhadap pembelajaran kompetensi pengetahuan ilmu pengetahuan sosial. Hal ini terlihat dari sebelum diterapkannya model pembelajaran Cooperatif Script dalam kelas siswa cenderung pasif dalam proses pembelajaran dan setelah diterapkannya model Cooperatif Script siswa menjadi lebih aktif karena siswa dilatih untuk menyampaikan pendapatnya dan mengoreksi hasil pekerjaan teman kelasnya. Keaktifan siswa ini dirasakan oleh guru dari sebelumnya siswa cuma mendengarkan dan sekarang menjadi lebih berpartisipasi dalam proses pembelajaran.

Hal ini berbeda dengan pembelajaran yang tidak menggunakan model Cooperatif Script pada kelas kontrol. Pembelajaran yang tidak menggunakan model Cooperatif Script yang diterapkan pada kelas kontrol, guru cendrung lebih aktif sebagai sumber informasi bagi siswa. Kepasifan siswa menjadikan komunikasi yang terjalin hanya komunikasi satu arah yaitu antara guru dengan siswa. Sementara pada kelas eksperimen yang menerapkan model pembelajaran Cooperatif Script berbasis Tri Hita Karana siswa menjadi lebih aktif karena siswa dituntut belajar lebih banyak sehingga waktu dalam proses belajar tidak terbuang percuma, mengingat model pembelajaran Cooperatif Script berbasis Tri Hita Karana mengharuskan siswa agar lebih cepat menangkap materi pelajarandengan memperhatikanlandasan Tri Hita Karana terutama pada komponen pawongan, karena model pembelajaran Cooperatif Script berbasis Tri Hita Karana menuntut kerjasama antar kelompok. Selain komponen pawongan siswa juga selalu diingatkan untuk mengimplementasikan komponen parhayangan dengan berdoa diawal dan di akhir pembelajaran. Selain kedua komponen tersebut, komponen pelemahan juga perlu diimplementasikan melalui kebersihan tempat belajar untuk menciptakan suasana nyaman. Pada temuan yang didapat terkait implementasi palemahan adalah kondisi saat proses pembelajaran berlangsung berjalan dengan kondusif karena tidak ada gangguan dari luar seperti suasana bising dari lingkungan yang menyebabkan siswa kurang fokus pada saat pembelajaran berlangsung. Dengan demikian hasil penelitian ini membuktikan bahwa model pembelajaran Cooperatif Script berbasis Tri Hita Karana memberikan pengaruh positif terhadap hasil belajar kognitif siswa kelas IV pada mata pelajaran kompetensi pengetahuan ilmu pengetahuan sosial di Gugus IV Kecamatan Tampaksiring Kabupaten Gianyar tahun pelajaran 2018/2019.

Hambatan yang ditemukan saat melakukan penelitian pada kelas eksperimen tidak terlalu berarti. Hanya saja ada beberapa hambatan kecil seperti masih terdapat beberapa siswa yang kurang fokus dalam mengikuti proses pembelajaran tetapi hal tersebut sudah dapat ditanggulangi oleh guru dengan memberikan perhatian lebih kepada siswa yang bersangkutan. Sementara hambatan di kelas kontrol lebih banyak ditemukan. Hambatanhambatan tersebut yaitu banyak ditemukan siswa yang kurang memperhatikan guru saat 
I Kadek Wibisana, Ni Nyoman Kusmariatni, Kadek Yudiana. (2019). Jurnal Pendidikan Multikultural Indonesia. Vol. 2 (2) pp. 66-75.

menjelaskan materi, selain itu terdapat pula beberapa siswa yang bercanda pada saat proses pembelajaran berlangsung.

\section{SIMPULAN DAN SARAN}

Berdasarkan hasil pengujian hipotesis dan pembahasan, maka temuan dalam penelitian ini menyatakan bahwa terdapat pengaruh Model Pembelajaran Cooperatif Script Berbasis Tri Hita Karana Terhadap kompetensi Pengetahuan IPS. Hasil analisis menunjukan bahwa $t_{\text {hitung }}$ adalah 3,062 sedangkan nilai $t_{\text {tabel }}$ dengan taraf signifikan $5 \%$ adalah 2,000. Rata-rata kompetensi pengetahuan IPS siswa yang menggunakan Model Pembelajaran Cooperatif Script Berbasis Tri Hita Karana adalah 20,78 termasuk kategori tinggi dan rata-rata pemahaman kelompok siswa yang menggunakan model pembelajaran konvensional 16,86 termasuk kategori sedang. Hal ini berarti, rata-rata kompetensi pengetahuan IPS kelompok siswa yang mengikuti Model Pembelajaran Cooperatif Script Berbasis Tri Hita Karana lebih besar daripada rata-rata kompetensi pengetahuan IPS kelompok siswa yang menggunakan model pembelajaran konvensional. Berdasarkan data di atas dapat disimpulkan bahwa terdapat perbedaan yang signifikan kompetensi pengetahuan IPS antara kelompok siswa yang dibelajarkan menggunakan model pembelajaran Cooperatif Script dengan kelompok siswa yang dibelajarkan menggunakan model konvensional pada siswa kelas IV di Gugus IV Kecamatan Tampaksiring.

Berdasarkan penelitian yang telah dilakukan, saran yang bisa disampaikan yaitu sebagai berikut. Pertama, bagi siswa di Sekolah Dasar agar lebih aktif dalam mengikuti pembelajaran dan terus mengembangkan pemahamannya dengan selalu berusaha membangun sendiri pengetahuan tersebut melalui pengalaman. Kedua, bagi guru di Sekolah Dasar agar lebih berinovasi dalam pembelajaran dengan menerapkan model pembelajaran Cooperatif Script untuk dapat meningkatkan kompetensi pengetahuan IPS siswa. Ketiga, bagi kepala sekolah yang mengalami penelitian ini dijadikan sebagai sumber informasi dalam pengembangan pendidikan dengan beragamnya model pembelajaran yang ada. Keempat, bagi peneliti yang berminat untuk mengadakan penelitian lebih lanjut tentang pengaruh Model Pembelajaran Cooperatif Script Berbasis Tri Hita Karana terhadap kompetensi pengetahuan IPS maupun bidang ilmu lainnya yang sesuai agar memperhatikan kendala-kendala yang dialami dalam penelitian ini sebagai bahan pertimbangan untuk perbaikan dan penyempurnaan penelitian yang akan dilaksanakan.

\section{DAFTAR RUJUKAN}

Huda, M. 2014. Model-model Pengajaran dan Pembelajaran. Yogyakarta: Pustaka Pelajar.

Kurniasih, Imas dan Berlin Sani. 2016. Ragam Pengembangan Model Pembelajaran. Kata Pena.

Laksmi, N. P. W., Parmiti, D. P., \& Kusmariyatni, N. 2013. "Pengaruh Pendekatan Sains Teknologi Masyarakat Bermuatan Kearifan Lokal Tri Hita Karana Terhadap Sikap IImiah Siswa Kelas IV SD Negeri 1 Ubud". Mimbar PGSD Undiksha, Vol.1. No. 1.

Purwanto, N. 2014. Pengantar Pendidikan. Yogyakarta: Graha Ilmu.

Shoimin, Aris. 2014. 68 Model Pembelajaran Inovatif dalam Kurikulum 2013. Yogyakarta: Arruzz Media.

Tjandra, M,dkk. 2005. Pendidikan IImu Pengetahuan Sosial Di Sekolah Dasar. Singaraja: Undiksha.

Suja, I W. 2010. Kearifan Lokal Sains Asli Bali. Surabaya: Paramita.

Pengaruh Model Cooperatif Script Berbasis Tri Hita Karana Terhadap Kompetensi Pengetahuan Ips 
I Kadek Wibisana, Ni Nyoman Kusmariatni, Kadek Yudiana. (2019). Jurnal Pendidikan Multikultural Indonesia. Vol. 2 (2) pp. 66-75.

Trianto. 2012. Model Pembelajaran Terpadu Konsep, Strategi, dan Implementasinya Dalam Kurikulum Tingkat Satuan Pendidikan (KTSP). Jakarta: PT Bumi Aksara.

Yulianto, I. E. 2014. "Penggunaan Model Kooperatif Tipe Cooperative Script dalam Peningkatan Pembelajaran IPS pada Siswa Kelas V SD Negeri Widarapayung Wetan 02 Tahun Ajaran 2013/2014". Kalam Cendekia Pgsd Kebumen, Vol. 5, No.3 